Wioletta Krawiec
University of Lodz

\title{
BUILDING A BRAND FOR THE CITY OF LODZ: MOTIVATING AND DEMOTIVATING FACTORS FOR MANAGERS OF CULTURAL INSTITUTIONS
}

The article aims to identify areas/factors that may motivate or discourage managers of cultural institutions from getting actively involved in the process of building the Lodz brand for cultural resources.

The article describes the manager profile of cultural institutions and presents an ordered list of factors (stimuli) that have a positive or negative impact on the activities of managers of cultural institutions in the area of creating the city brand.

The empirical basis of the article is interviews with managers and promotion employees in the city's cultural institutions in Lodz. Data analysis was carried out by the principles of grounded theory methodology. The research has been carried out since December 2017 within the Department of Marketing and the Department of City and Region Management of the Faculty of Management at the University of Lodz as part of the project: "Cooperation of public administration with cultural institutions in the context of building a city brand".

Keywords: city brand, manager, grounded theory, cultural institutions, motivators, de-motivators JEL Codes: M14, M31

\section{Introduction}

Today's cultural institutions need professionals who think like innovators and manage like businesspeople. Currently, cultural managers are expected to have creative ideas (creative solutions), the ability to see opportunities and threats in the future, and flexible adaptation to changes in the environment. ${ }^{1}$ It is also related to the fact that the documented level of education of the employed workers is becoming less and importing less. Modern technology enables people to access knowledge and gather different experiences faster. However, technologies are developing more quickly than many people are able to acquire new skills. Therefore, there is a belief that soft skills will be the primary influence on the success of modern organizations, replacing the lack of hard skills of their employees. ${ }^{2}$ Remote or individualized work styles, and generational

\footnotetext{
${ }^{1}$ S. Kania: Przewódca jako kreator zmian w organizacji, „Menagement Forum”, vol. 3, no. 2, 2015, ss. 38-43; W. Krawiec: Kreatywność jako determinanta tworzenia wartości i pogłębiania doświadczeń jej odbiorców, Prace naukowe Uniwersytetu Ekonomicznego we Wrocławiu, nr 529, 2018, ss. 129-139; R. W. Woodman, J. E. Sawyer, R. Griffin: Toward a Theory of Organizational Creativity, „A Academy of Management Review" vol. 18 (2), 1993; J. D. Wadden: Marketing creativity: the influence of personal and proximal work factors on creative activity, „Marketing Management Journal", vol. 21 (2), 2011, s. 73; Report GUS: Działalność innowacyjna przedsiębiorstw $w$ Polsce $w$ latach 2013-2015, s. 41-63.

${ }^{2}$ M. Bellon, Szefowa IBM uważa, że zatrudnianie ludzi na podstawie dyplomu, jest błędem, Business Sinder Polska, https://businessinsider.com.pl/rozwoj-osobisty/kariera/kariera-w-branzy-technologicznej-radyszefowej-ibm/esre9wc (z dnia: 10.02.2019).
} 
differences, mean that other factors can motivate or demotivate employees. Research in this area is conducted mainly for large organizations, but there are not many publications in the area of cultural institution management. Usually these publications are targeted at public administration employees. ${ }^{3}$

In this article, the scope of changes in the business world described above was referred to managers and employees of the city's cultural institutions in Lodz. Based on the conducted interviews and their analysis, in accordance with the principles of grounded theory methodology, the author of the paper managed to identify/categorise the profile of the manager of a cultural institution (CI) and the factors motivating or demotivating employees of cultural institutions in the process of building the brand of the city of Lodz, taking into account its cultural resources.

The reference of considerations to cultural resources results from brand strategy adopted by this city of Lodz. It should be mentioned here that the cultural resources of the city of Lodz are one of the city sub-products accepted and recorded in the document titled "The Brand Management Strategy for the years 2010-2016", which specified the direction for building the city's brand based on culture, new media and creative industry. In order to understand the essence and potential of the creative approach to the city's brand, a document describing activities related to the development of culture, entitled “Culture Development Policy 2020+ for the City of Lodz", was prepared. 5

The results of the research presented in the article are a part of a larger research project conducted within the Department of Marketing and the Department of City and Region Management of the Faculty of Management at the University of Lodz entitled "Cooperation between public administration and cultural institutions in the context of building a city's brand".

\section{Managers of cultural institutions and building the city's brand for cultural resources}

Building the city's brand is influenced not only by the city's resources but also by the people who can be able to use these resources. Through them, the brand can articulate its values, which are reflected in the city image. The city's brand should be regarded as a particularly complex and multidimensional construct, as it results from the complexity of the territorial

\footnotetext{
${ }^{3}$ E.g. L. Bright's research refers to the relationship between public service motivation and personality traits, management level and financial preferences of public sector employees. The results show that public sector employee motivation is to a large extent related to gender, educational level, level of management and financial preferences of public sector employees. The implications of this study and the areas of future research are discussed. Look at the research in more detail: L. Bright, Public Employees With High Levels of Public Service Motivation: Who Are They, Where Are They, and What do They Want?, "Review of Public Personnel Administration", Vol. 25. 2, 2005, pp. 138-154; L. Bright, Where Does Public Service Motivation Count the Most in Government Work Environments? A Preliminary Empirical Investigation and Hypotheses, "Public Personnel Management", Vol.42, 1, 2013, pp. 5-26; L. Bright, Why Age Matters in the Work Preferences of Public Employees: A Comparison of Three Age-Related Explanations, "Public Personnel Management", Vol. 39, 1, 2010, pp. 1-14; and research: S. Park, Motivation of Public Managers as Raters in Performance Appraisal: Developing a Model of Rater Motivation, "Public Personnel Management", Vol. 43, 4, 2014 ; pp. 387-414; B. E Wright, S. Kim, Participation's Influence on Job Satisfaction: The Importance of Job Characteristics, "Review of Public Personnel Administration", 24, 1, 2004, pp. 18-40.

${ }^{4}$ Original title (Polish): Strategia Zarzqdzania Marka Lódź na lata 2010-2016, s. 17-30.

${ }^{5}$ Original title (Polish): Polityka Rozwoju Kultury 2020+ dla Miasta Lodzi.
} 
product. The city, similar to a company, offers its current and potential users certain products, both tangible and intangible, in the broadly understood spatial structure of the city, which become the subject of the market exchange. ${ }^{6}$ The city's brand, therefore, connects both material elements that constitute the city's reality (infrastructure, architecture, tourism development) and intangible aspects (values and beliefs). ${ }^{7}$ The process of building a city's brand is significantly different from the process of creating a consumer product brand. These differences come down mainly to the objectives, the level of diversification of consumer groups and the complexity of the process. ${ }^{8}$

In the process of creating a city's brand based on cultural resources, the managers of cultural institutions (CI) can play a significant role. They become, to some extent, the guardians of the city's proper image. This requires cultural institutions to employ managers with an appropriate profile. It is not a simple task for any organisation. Managerial psychology has long tried to create a list of features that should characterize an ideal manager. There are many approaches in the literature to describe managerial features, skills and competencies. ${ }^{9}$ The manager's profile is described in the following dimensions: professionally (professional qualifications and managerial competencies) and personally (managerial typology: visionary, analyst, contractor, observer, theoretician, pragmatist). ${ }^{10}$ It is worth mentioning here the profile of the manager of the so-called "new era", whose work should be based on the 3-C model: communication, creativity, cohabitation. ${ }^{11}$ This approach is associated with a demanding market today, in which creative managers are required. ${ }^{12}$ More attention is given to the soft skills of managers, which influence the success of a modern organisation. ${ }^{13}$

Therefore, the culture manager will be expected to have characteristics for creating a professional profile and intellectual potential. These should facilitate leading and managing a team of people, as well as achieving the common goals of cultural institutions. The desired characteristics of cultural managers are described in the

\footnotetext{
${ }^{6}$ T. Markowski: Marketing terytorialny, ,Studia KPZK PAN”, t. CXII, 2002.

${ }^{7}$ M. Korczyńska: Marka miasta, „Marketing i Rynek”, (12),2002, ss. 2-10.

${ }^{8}$ R. Seweryn: Kryzys gospodarczy a ewolucja marki Kraków w opinii hiszpańskich turystów, „Współczesne Zarządzanie", (1), 2013, ss. 51-61; Ph. Kotler, N. Lee: Marketing w sektorze publicznym. Mapa drogowa wyższej efektowności, Wyd. Akademickie i Profesjonalne, Wyższa Szkoła Przedsiębiorczości i Zarządzania im. L. Koźmińskiego, Warszawa 2008.

${ }^{9}$ A. Tomaszuk: Sylwetka menedżera $w$ świetle teorii zarzadzania i badań wlasnych na przykładzie menedżerów sektora budownictwa województwa podlaskiego, „Economics and Management”, nr 4, 2013, ss. 67-81; Z. Ciekanowski: Rola menedżera $w$ organizacji, „Zeszyty Naukowe Uniwersytetu PrzyrodniczoHumanistycznego w Siedlcach. Administracja i Zarządzanie”, z. 34, nr 107, 2015, ss. 185-195; M. Ciesielska: Lider poszukiwany. Jak stworzyć model kompetencji pożadanego lidera zespołu, „Personel 7 ”, 2007.

10 P.F. Drucker: Menedżer skuteczny, AE, Kraków 1994; C.S. Nosal: Psychologia myślenia i działania menedżera, AKADE, Kraków 2001; P. Wachowiak: Profesjonalny menedżer, Difin, Warszawa 2001.

${ }^{11}$ W. Wierżyński: Menedżerowie nowej ery, http://www.pi.gov.pl/PARP/chapter_86196.asp?soid=4A743DA96D4F422C94CAB3F7CACF3036, dostęp: 15.11.2018.

${ }^{12}$ M. Williams: Mistrzowskie przywództwo, Oficyna Wolters Kluwer Business, Kraków 2009; K. B. Simerson, M. L.Venn, Menedżer jako lider, Oficyna Wolters Kluwer Business, Warszawa; J. Penc:, Nowe zarzqdzanie w nowej gospodarce, Wydawca SLG International Training Center, Warszawa 2010.

${ }^{13}$ These soft skills, such as communication, interpersonal and social skills or emotional intelligence, are much more difficult to learn than, e.g. programming. Look more: M. Bellon, Szefowa IBM uważa, że zatrudnianie ludzi na podstawie dyplomu, jest błędem, Business Sinder Polska, https://businessinsider.com.pl/rozwojosobisty/kariera/kariera-w-branzy-technologicznej-rady-szefowej-ibm/esre9wc(z dnia: 10.02.2019).
} 
literature on the subject. The following can be mentioned here: sensitivity, honesty and credibility, perseverance, involvement and loyalty, ability to achieve the desired goal, high level of knowledge, belief in success. Types of behaviour such as positive attitude towards life and the environment, adaptability, ability to communicate, ability to build relationships, self-confidence and self-control are also associated with these characteristics. These behaviours require personal, interpersonal and strategic skills.

The main tasks of a contemporary cultural manager include the preparation of cultural projects (artistic undertakings and events); the obtaining of financial resources and patronage (sponsors); promotion and information on cultural ventures; contact with the media and external clients; cooperation with local, regional and international partners; coordination and supervision of the work of a team; the conduct of cultural education; animation of cultural life of local communities. ${ }^{14}$

\section{Motivating, engaging and demotivating employees in the organization}

Motivation isn't an unambiguous concept. ${ }^{15}$ It is a "psychological mechanism that triggers and organises human behaviour aimed at the achieved goal" ${ }^{16}$ Based on the organisation's management, motivation takes place through an incentive system. Such a system creates a schematic of logical and mutually supporting measures (stimuli) for motivation and conditions aimed at encouraging employees to engage in their work in the most beneficial way for the organization, as well as giving personal satisfaction to the employees themselves.

However, it should be noted that, for the motivating system scheme to function properly, its various elements have to take on a process form. The motivating process should take into account both the motivated employee and the motivating person. Within the first level, attention should be given to objectives in terms of relevance and usefulness; the effort to which the person should be convinced in terms of modifying their behaviour; the results achieved, which should be of positive value. On the other hand - motivating the employee, the correct (values, expectations) recognition of the motivated goals should be ensured. ${ }^{17}$

Only a motivated employee is assumed to be able to work effectively. It should be mentioned here, that a motivation system based on external rewards (money, awards, competition, prizes based on defined goals, etc.) does not cause people to be more motivated, and even to work worse, when oriented towards accomplishing material

\footnotetext{
14 Original title (Polish): Informacja o zawodzie - menedzer kultury, 2010, s. 4; P.S. Foehl, The Cultural Manager:Marginal Notes on a Discussion of Roles and Values, http://www.artsmanagement.net/3b9c996acd3299326518f8e1ff3ad82d,0fm.pdf (27.11.2019); P.S. Fohla, G. Wolframb, R. Peperc, Cultural Managers as 'Masters of Interspaces' in Transformation Processes - a Network Theory Perspective, „Zeitschrift für Kulturmanagement”, 1/2016, S. 17-49 (https://www.netzwerkkulturberatung.de/content/1-ueber/1-dr-patrick-s-foehl/1-publikationen/cultural-managers-as-masters-of-interspacesin-transformation-processes-a-network-theory-perspective/b38_zkm2016.1-xx-fohl-et-al-id033.pdf)

${ }_{15}$ M. Kostera, S. Kownacki, A. Szumski: Zachowania organizacyjne: motywacja, przywództwo, kultura organizacyjna, [w:] A. Koźmiński, W. Piotrowski: Zarzadzanie. Teoria i praktyka, Warszawa 2004, s. 315.

16 B. Kuc, J. Moczydłowska: Zachowania organizacyjne, Warszawa, 2009, s. 77; M. Argyle, The Social Psychology of Work, (2nd edn), Harmondsworth: Penguin1989.

${ }^{17}$ L. Indisowa, I. Kołodziejczyk-Olczak, Uwarunkowania skutecznego motywowania. Proces komunikacji, Łódź, 2000, s. 47.
} 
benefits. Much more engaging are stimuli from the group of internal motivators. ${ }^{18}$ These can include: challenges in the workplace; a sense of the reality of the task being performed; learning new things; personal development; independence in action. Other essential practices in this area include skillful delegation of functions and powers, employee involvement in setting goals for the organization and joint celebration of successes $^{19}$, as well as relations with supervisors and comfort at work (independence of the position, organizational culture of the company, ensuring work-life-balance). ${ }^{20}$

An appropriately constructed motivating system should trigger the employee's involvement, which will indicate their attitude towards the organisation. In social psychology, attitude is understood as an individual's permanent approach to someone or something. It includes three components: rational (perspective "I work here because I have no other choice"); emotional (reaction "I work here because I want to") and behavioural ("I work because I should"). ${ }^{21}$

From the perspective of the organization, the most valuable is involvement, which is manifested by initiating changes and taking responsibility for them, perceiving problems and making proposals for solving them, innovativeness, and searching for new professional challenge $\mathrm{e}^{22}$

However, the question often arises, why despite the specific motivation system for employees, does it not work? The report prepared by "ARC Market and Opinions" shows that the most discouraging factors for managers to continue working include complicated relationships with their supervisors and illegal objectives. ${ }^{23}$ These are often the main reasons for resignation from work.

\section{Profile of managers of cultural institutions and factors motivating / demotivating their involvement in the city of Lodz's branding process of cultural resources - research results}

\section{Method research}

The scope of the analysed research results is dictated by the purpose of the article, the state of the available data and the adopted method of their analysis and deduction. The information for review in this article comes from 15 purposely selected interviews with

\footnotetext{
${ }^{18}$ S. Park, Motivation of Public Managers as Raters in Performance Appraisal: Developing a Model of Rater Motivation, „Public Personnel Management”, Vol. 43, 4, 2014; pp. 387-414.

${ }^{19}$ M. Wójtowicz, Tajemnice motywacji - trzy spojrzenia na problem motywacji pracowników, Good Point, https:/goodpoint.blog/tajemnice-motywacji-trzy-spojrzenia-na-problem-motywacji-pracownikow/ (z dnia: 24.04. 2017).

${ }^{20}$ Report: Motywacje menadżerów 2016, ARC Rynek i opinie, Warszawa 2016; M. Matejun, S. Dębska, NonEconomic Incentives to Motivate Employees - Lodz Branch of Norauto Polska Ltd. Example, [in:] D. Lewicka (red.), Organisation Management. Competitiveness, Social Responsibility, Human Capital, AGH University of Science and Technology Press, Krakow 2010, pp. 91-112; L. Machara and P. Jain, Factors affecting staff motivation in public libraries: a case of selected public libraries in Botswana, „Mousaion: South African Journal of Information Studies", Vol. 34, 1, 2016, pp. 101 - 122.

${ }^{21}$ G. Lindzey, E. Aronson: Handbook of Social Psychology, New York, Random House, 1985; J.P. Meyer, N.J. Allen, A Tree-Component Conceptualization on Organizational Commitment, „Human Resource Management Review" 1991, No. 1, ss. 61-89.

${ }^{22} \mathrm{H}$. Guryn, Czy warto mierzyć zaangażowanie pracowników, „Personel i Zarządzanie” 2009, nr 4.

${ }^{23}$ Report: Motywacje menadżerów 2016, ARC Rynek i opinie, Warszawa 2016.
} 
managers and promotion specialists employed in city cultural institutions subordinate to the City of Lodz Office (approx. 30\% of surveyed managers of cultural institutions in Lodz). ${ }^{24}$ From the answers of the respondents, it can be concluded that all the people participating in the study have higher education. The respondents work in cultural institutions such as theatres, museums, cultural centres, libraries, sports and cultural institutes.

The interviews were transcribed and then, following the accepted aim of the article and the principles of grounded theory methodology, the so-called theoretical sampling and coding were undertaken. ${ }^{25}$ This analysis also allowed to determine the purpose of this article.

It should also be mentioned here that the ground theory assumes researching without formulating any research hypotheses; at most, there may be so-called initial assumptions, which, based on the research, may evolve or create new ones. It is also possible not to have them at all. The ground theory gives the researcher the possibility to discover new phenomena, concepts, theories, classifications or, as a result, to find relations between categories, which may be the starting point for the formulation of research hypotheses. ${ }^{26}$

The categories and codes presented in the article are the results of analyses carried out using the adopted research procedure on the methodology of grounded theory. Respondents were not given any definitions or assumptions during the research. Throughout the study, the questions asked were broadened or shortened; the reason for this was the research direction and the adopted research strategy, which was not limited to respondents. It should be mentioned that in qualitative research, the basis of the analysis is induction, i.e. creating generalisations based on detailed information obtained from the collected data. These studies are only cognitive in nature and help to understand or explore a new trend. ${ }^{27}$

The results presented in the article are subject to certain limitations. In the article, not all the codes adopted in the study were written down due to their large number. The article narrows down the discussion to 15 statements by representatives of municipal cultural institutions subordinate to the City Office. Therefore, this study cannot be treated as representative. The article omits descriptions of existing relations/assumptions between separate categories, which would allow considering a more significant number of problematic threads or development of other hypotheses. The paper also does not quote managers' statements. The results of the analysis are presented in tables, due to the publication limitations of the article. The observed phenomena was organised this way in order to make the areas describing the CI manager's profile, and the factors motivating

\footnotetext{
${ }^{24}$ In the whole research project, 50 representatives of cultural institutions in Lodz, subordinate to the City of Lodz Office, as well as to the Marshal of the Lodz Province, joined the research. The research was carried out by the cultural institutions that agreed to participate in the survey.

${ }_{25}$ The main elements of grounded theory are theoretical sampling, coding, theoretical saturation and continuous comparison. Patrz: K. Konecki: Studia z metodologii badań jakościowych. Teoria ugruntowana, Warszawa, PWN,2000, s. 26.

${ }^{26}$ Hypotheses, concepts and properties of ideas are built during empirical research; during that time, they are also modified and verified. Patrz: K. Konecki: Studia z metodologii ..., PWN, s. 26.

${ }^{27}$ J. Niedbalski: Komputerowe wspomaganie analizy danych jakościowych. Zastosowanie oprogramowania NVIVO i Atlas.TI w projektach badawczych opartych na metodologii teorii ugruntowanej, Wyd. UŁ, Łódź, 2014.
} 
and demotivating them to get involved in building the brand of the city of Lodz in the area of cultural resources, more readable.

\section{Profile of managers of cultural institutions in Lodz}

Table 1 contains features describing the profile of the CI manager that emerged in the course of research. ${ }^{28}$

Tabela 1. Profile of a cultural institution employee

\begin{tabular}{|c|c|c|c|c|}
\hline $\begin{array}{l}\text { Codes based on the } \\
\text { in-depth } \\
\text { theoretical } \\
\text { sampling of the } \\
\text { analysed interview } \\
\text { content (selective } \\
\text { approach) }\end{array}$ & $\begin{array}{l}\text { Grouping of } \\
\text { selective codes }\end{array}$ & $\begin{array}{l}\text { Grouped } \\
\text { subcategories } \\
\text { constituting } \\
\text { the values of } \\
\text { the categories }\end{array}$ & $\begin{array}{l}\text { Description of the main } \\
\text { categories' values }\end{array}$ & $\begin{array}{c}\text { Main } \\
\text { categories }\end{array}$ \\
\hline $\begin{array}{l}\text { - involved person } \\
\text { - observer } \\
\text { - optimist } \\
\text { - target-oriented } \\
\text { person } \\
\text { - communicative } \\
\text { person }\end{array}$ & personality & $\begin{array}{l}\text { psychological } \\
\text { maturity }\end{array}$ & \multirow{3}{*}{$\begin{array}{l}\text { - to the psyche, it is } \\
\text { understood as a stage of } \\
\text { shaping a person's personality, } \\
\text { i.e. a set of psychological traits } \\
\text { appropriate for a person, } \\
\text { testifying to their individuality, } \\
\text { which makes it possible to } \\
\text { formulate opinions and make } \\
\text { decisions. } \\
\text { - it is a period in which the } \\
\text { physical and psychic } \\
\text { characteristics of a human } \\
\text { being enable them to function } \\
\text { in society, reproduction, } \\
\text { - consists of physical, psychic } \\
\text { and social maturity. }\end{array}$} & \multirow{3}{*}{ 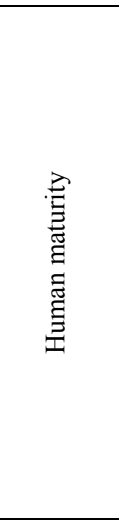 } \\
\hline $\begin{array}{l}\text { - social/local } \\
\text { patriotism (proud } \\
\text { patriot) } \\
\text { - organisational } \\
\text { patriotism (proud } \\
\text { manager) } \\
\end{array}$ & societal views & social maturity & & \\
\hline- age & $\begin{array}{l}\text { - human } \\
\text { development period }\end{array}$ & $\begin{array}{l}\text { physical } \\
\text { maturity }\end{array}$ & & \\
\hline- & $\begin{array}{l}\text { - chairperson, } \\
\text { director, manager, } \\
\text { supervisor, leader } \\
\text { - former workplace }\end{array}$ & workplace & \multirow{6}{*}{$\begin{array}{l}\text { - it is the job seniority, } \\
\text { workplace, education, industry } \\
\text { in which he worked, scope of } \\
\text { duties and responsibility for } \\
\text { them, skills acquired in the } \\
\text { course of their performance. }\end{array}$} & \multirow{6}{*}{ 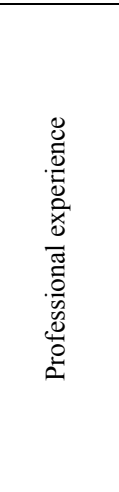 } \\
\hline - & $\begin{array}{l}\text { - clerk } \\
\text { - businessman } \\
\text { - non-governmental } \\
\text { worker }\end{array}$ & $\begin{array}{l}\text { experience in } \\
\text { the } \\
\text { industry/sector }\end{array}$ & & \\
\hline- & $\begin{array}{l}\text { - profession } \\
\text { - speciality } \\
\text { - scientific title (MA, } \\
\text { PhD) }\end{array}$ & education & & \\
\hline- & - & skills & & \\
\hline- & - & job seniority & & \\
\hline- & - & workplace & & \\
\hline
\end{tabular}

Source: Author's own study based on research.

Based on the results of the ordered ranking in Table 1, it can be observed that two main categories describe the profile of the CI manager who is partially responsible for

${ }^{28}$ The described set of categories in Table 1 is the 5 th version of the in-depth study. The categories are given a basis for building a theory within them. The selected categories may be further transformed in the course of research. 
creating the city of Lodz brand in the area of cultural resources. These categories are called "human maturity" and "professional experience". The description of the main categories was possible due to the analysis and coding described in the methodology of this article. Under the category "human maturity" subcategories such as "psychological maturity" in the context of a manager's personality are described. In this subcategory, during theoretical sampling, such a manager emerged as one who is engaged, an observer, an optimist, a goal-oriented person, a communicative person.

The second subcategory of "human maturity" is "social maturity". Social maturity describes "social/local/organisational patriotism", i.e. love and attachment to one's own local fatherland, place of residence or birth, pride in one's own company. Such people who identify themselves with the place are more inclined to do something for the city. The last subcategory of "human maturity" is "physical maturity" - the period of human development - "age". It is a definition of the state of "physical maturity" (in biology it refers to the organism) and "psychological maturity" of a person (male or female) who is not a child. At the same time, it is the subcategory that had the least meaning in the conducted research. The persons studied were aged $30-50$ years.

The second category is not surprising when it comes to the employee profile. The subcategories defined within it are the central areas that are usually described in each employee's CV (Curriculum Vitae). The subcategories distinguished here include job position (current and former), industry/sector experience, education, skills in a broad sense, job tenure, job place of employment. However, within them, the author of the article underlined the particular importance of the subcategory "experience in the industry/sector - official, entrepreneur, non-governmental worker". It might be an essential criterion that will have a huge impact on the perception of the world but will also influence the manager's performance in the environment in which he or she works. Within this category, it is also possible to find dependencies between the subcategories "workplace" and "skills".

On the other hand, the subcategory "industry/sector experience" may be significantly related to the subcategory "psychological maturity - personality" from the category "human maturity". One of the main categories which deserves attention is "human maturity", which seems to significantly dominate over "professional experience". The "personal" characteristics within this category may be more important and necessary at work than those resulting from work experience.

Factors motivating and demotivating the CI manager to engage in building the brand of the city of Lodz for cultural resources

Table 2 is the result of interviews conducted among managers of cultural institutions in Lodz. Separate categories organize and describe the scope of content spoken in the process of research. Recording the research results in a table was aimed at easier readability of the observed phenomena. Based on the research, two main categories were distinguished, internal (Table 2) and external (Table 3) factors, whose more in-depth explanation and description is found in the tables. 
Table 2. Internal factors (stimuli) from the group of motivators and demotivators influencing the involvement of cultural institution (CI) employees in building the city's brand for Lodz

\begin{tabular}{|c|c|c|c|}
\hline \multirow{2}{*}{$\begin{array}{c}\text { Grouped } \\
\text { subcategories } \\
\text { constituting the } \\
\text { values of the main } \\
\text { category, i.e. } \\
\text { internal factors }\end{array}$} & \multicolumn{3}{|c|}{$\begin{array}{l}\text { Codes based on the deepened theoretical sampling of analysed interview contents } \\
\text { (selective approach) }\end{array}$} \\
\hline & $\begin{array}{c}\text { Description of } \\
\text { subcategory values }\end{array}$ & Motivator present based on studies & Demotivator present based on research \\
\hline attitude/mentality & $\begin{array}{l}\text { - the approach of } \\
\text { CI employees to } \\
\text { actions aimed at } \\
\text { building a city's } \\
\text { brand with their } \\
\text { participation }\end{array}$ & $\begin{array}{l}\text { - willingness to learn from others, } \\
\text { getting to know partners' work } \\
\text { techniques and willingness of CI } \\
\text { employees to work "for ideas", } \\
\text { create something unique and of } \\
\text { good quality; } \\
\text { - identification with one's own city } \\
\text { facilitates work and tasks related to } \\
\text { its brand (local patriotism); } \\
\text { - appreciation of NGOs } \\
\text { cooperation; } \\
\text { - culturally aware managers } \\
\text { ("working in CI is a state of } \\
\text { mind"); appreciation of } \\
\text { professional management; } \\
\text { "elimination of people from the } \\
\text { situation"; } \\
\text { - a positive attitude of CI managers } \\
\text { towards planned and measurable } \\
\text { activities }\end{array}$ & $\begin{array}{l}\text { - lack of ability to be inspired by } \\
\text { documents developed to build a city's } \\
\text { brand; disrespectful attitude towards } \\
\text { documents, and their entries are treated } \\
\text { as "unnecessary dizziness"; } \\
\text { - employees of CI say that the } \\
\text { assumptions about the development of } \\
\text { the Lodz brand "are often omitted"; } \\
\text { - the reluctance of CI employees for } \\
\text { large events, although they understand } \\
\text { their need to organise events for visitors } \\
\text { to the city; } \\
\text { - lack of thinking about the benefits of } \\
\text { getting involved in building a city's } \\
\text { brand on the part of CI employees; } \\
\text { - lack of willingness in most CIs to take } \\
\text { responsibility and take risks related to } \\
\text { building a city brand, because "no one } \\
\text { will give a reward for it"; } \\
\text { - lack of professional managerial } \\
\text { approach, conviction that in CI } \\
\text { "everyone can manage"; } \\
\text { - failure to see the effects of their own } \\
\text { actions discourages managers }\end{array}$ \\
\hline $\begin{array}{l}\text { cooperation/ } \\
\text { relationships }\end{array}$ & $\begin{array}{l}\text { - creating ties and } \\
\text { cooperation with } \\
\text { others, need to } \\
\text { work in a group to } \\
\text { achieve common } \\
\text { goals, willingness } \\
\text { to perform tasks in } \\
\text { a team and solve } \\
\text { problems together } \\
\text { - it is an emotional } \\
\text { competence; it } \\
\text { determines the } \\
\text { quality of relations } \\
\text { with other people }\end{array}$ & $\begin{array}{l}\text { - possibility for CI to consult with } \\
\text { the city government in order to get } \\
\text { to know the parties' opinions; } \\
\text { share own experience, knowledge; } \\
\text { get to know partners and deepen } \\
\text { ties between participants in } \\
\text { meetings, etc.; } \\
\text { - individual (personal) approach to } \\
\text { CI employees raises the level of } \\
\text { confidence, recognition and } \\
\text { identification with the tasks } \\
\text { performed; } \\
\text { - mutual acceptance of the parties } \\
\text { (CI employee, city authorities, } \\
\text { external entities, e.g. NGOs and } \\
\text { other companies) deepen the } \\
\text { relations between them and allows } \\
\text { to achieve strategic and } \\
\text { operational goals (e.g. raising } \\
\text { money for projects, renting of } \\
\text { exhibits from other institutions, } \\
\text { etc.); } \\
\text { - high personal culture of } \\
\text { employees and their level of } \\
\text { education provides the basis for } \\
\text { development at various levels of } \\
\text { cooperation; } \\
\text { - cooperation with external entities } \\
\text { (e.g. NGOs) enables the creation } \\
\text { of interesting project teams; } \\
\text { - the task of the CI employees, } \\
\text { openness and willingness to } \\
\text { engage in dialogue is the basis for }\end{array}$ & $\begin{array}{l}\text { - consultations, meetings with nothing to } \\
\text { do "Pro-forma meetings"; } \\
\text { - too rare cooperation of CI with city } \\
\text { government, e.g. due to lack of money; } \\
\text { there is a need for more frequent } \\
\text { dialogue between cultural institutions; } \\
\text { - lack of twinning programmes between } \\
\text { other cities; } \\
\text { - lack of sense of inspiration from the } \\
\text { documents developed for city branding; } \\
\text { - omitting some CI to participate in tasks } \\
\text { for the city's brand, e.g. developing } \\
\text { documents }\end{array}$ \\
\hline
\end{tabular}




\begin{tabular}{|c|c|c|c|}
\hline & & cooperation & \\
\hline $\begin{array}{l}\text { sense of purpose/ } \\
\text { achievement/ } \\
\text { effect }\end{array}$ & $\begin{array}{l}\text { - a feeling of the } \\
\text { sense that the tasks } \\
\text { performed mean } \\
\text { something } \\
\text { important is being } \\
\text { done that gives a } \\
\text { real impact for the } \\
\text { good of the city's } \\
\text { brand }\end{array}$ & $\begin{array}{l}\text { - in cultural institutions are people } \\
\text { with passion and visions of the } \\
\text { development of the city of Lodz; } \\
\text { - a formal written process of } \\
\text { activities allows to implement } \\
\text { tasks in life; they have a real } \\
\text { impact; } \\
\text { - the documents show the essence } \\
\text { of the actions, but "they make } \\
\text { sense when they transform into a } \\
\text { strategy." }\end{array}$ & $\begin{array}{l}\text { - lack of sense of efficiency, nonsense; } \\
\text { - goals/tasks defined in an unclear way, } \\
\text { cause doubts and reluctance; lack of } \\
\text { "seeing" what is pursued in common } \\
\text { cooperation; } \\
\text { - the need to see one's own place in the } \\
\text { process of brand building; } \\
\text { - psychological pressure that there is not } \\
\text { enough time for everything; } \\
\text { - lack of effectiveness of meetings, } \\
\text { feeling of wasting time; } \\
\text { - the senselessness of frequent events } \\
\text { that do not translate into cultural quality; } \\
\text { - the need to define measures that allow } \\
\text { checking the effects of work }\end{array}$ \\
\hline $\begin{array}{l}\text { appreciation/ } \\
\text { confidence/ } \\
\text { involvement }\end{array}$ & $\begin{array}{l}\text { - attention and } \\
\text { appreciation from } \\
\text { the government for } \\
\text { what they do for } \\
\text { the city; } \\
\text { recognition often } \\
\text { results in greater } \\
\text { involvement of } \\
\text { employees in city } \\
\text { branding }\end{array}$ & $\begin{array}{l}\text { - appreciation/respect for their own } \\
\text { work and work of other } \\
\text { institutions for what they do; } \\
\text { - engaging cultural institutions in } \\
\text { the city's big projects allows them } \\
\text { to get involved in building the } \\
\text { city's brand; } \\
\text { - respect for the separateness of } \\
\text { institutions and specialisation } \\
\text { allows for effective } \\
\text { implementation of projects for the } \\
\text { city's brand }\end{array}$ & $\begin{array}{l}\text { - not all cultural institutions are } \\
\text { recognised as opinion-making } \\
\text { environments having an impact on } \\
\text { building a city's brand strategy; } \\
\text { - lack of boasting of niche institutions by } \\
\text { the city government; } \\
\text { - lack of "understanding and confidence } \\
\text { by the city government that CI can do } \\
\text { something", more independence is } \\
\text { needed; }\end{array}$ \\
\hline $\begin{array}{l}\text { sense of } \\
\text { development }\end{array}$ & $\begin{array}{l}\text { - feeling the state } \\
\text { of personal/ } \\
\text { individual } \\
\text { improvement of } \\
\text { one's own skills } \\
\text { over a specified } \\
\text { time }\end{array}$ & $\begin{array}{l}\text { - the possibility of exposing the } \\
\text { creative activities of a given } \\
\text { person or institution for the benefit } \\
\text { of the city brand; } \\
\text { - possibility of learning from } \\
\text { others during project cooperation } \\
\text { with different entities; } \\
\text { - feeling the need for a planned } \\
\text { and measurable action that can be } \\
\text { verified over time }\end{array}$ & $\begin{array}{l}\text { - lack of possibility of realization of fully } \\
\text { imposed mission/aims/tasks by CI due to } \\
\text { conditions, e.g. condition and surface of } \\
\text { the building; too short execution time; or } \\
\text { badly delegated task - not fully } \\
\text { consistent with the character of a given } \\
\text { CI; } \\
\text { - lack of information in the CI, what is } \\
\text { required of them in terms of branding; }\end{array}$ \\
\hline $\begin{array}{l}\text { independence / } \\
\text { resourcefulness }\end{array}$ & $\begin{array}{l}\text { - ability to cope } \\
\text { with difficult } \\
\text { conditions } \\
\text { resulting from a } \\
\text { lack of money, } \\
\text { people, place, } \\
\text { ideas, etc. }\end{array}$ & $\begin{array}{l}\text { - ability to cope with difficult } \\
\text { conditions resulting from } \\
\text { insufficient space, building } \\
\text { conditions, lack of money, lack of } \\
\text { people to perform tasks; } \\
\text { - ability to use the creativity of } \\
\text { employees of CIs; }\end{array}$ & $\begin{array}{l}\text { - employees' potential not fully } \\
\text { exploited, } \\
\text { - more projects are needed to harness the } \\
\text { potential of CI employees to build their } \\
\text { own brand and the city }\end{array}$ \\
\hline \multirow[t]{2}{*}{$\begin{array}{l}\text { communication/ } \\
\text { feedback }\end{array}$} & $\begin{array}{l}\text { - ability to } \\
\text { exchange } \\
\text { information, } \\
\text { communicate } \\
\text { between the CI and } \\
\text { the municipality } \\
\text { and other entities, } \\
\text { mental way of } \\
\text { information } \\
\text { processing }\end{array}$ & $\begin{array}{l}\text { - possibility of expressing one's } \\
\text { own opinion during consultations } \\
\text { - providing documents describing } \\
\text { how to build a brand of cultural } \\
\text { resources in accordance with the } \\
\text { adopted strategy of the city }\end{array}$ & $\begin{array}{l}\text { - lack of feedback on whether the } \\
\text { municipality appreciates the } \\
\text { submitted/implemented ideas by the CI; } \\
\text { - due to its specificity/variety of CI, there } \\
\text { are no clearly defined rules for the } \\
\text { selection/integration of a given CI into } \\
\text { actions for the city's brand; } \\
\text { - way of entries in documents sometimes } \\
\text { blocks actions, incomprehensibility, } \\
\text { inadequacy }\end{array}$ \\
\hline & $\begin{array}{l}\text { - ability to see } \\
\text { many places that } \\
\text { are not used for } \\
\text { branding purposes } \\
\text { and the ability to } \\
\text { use them in an } \\
\text { interesting way }\end{array}$ & $\begin{array}{l}\text { - recognising different niche } \\
\text { institutions/activities/places in the } \\
\text { city within which the image of the } \\
\text { city can be built; be able to use } \\
\text { them creatively }\end{array}$ & $\begin{array}{l}\text { - many unused areas of Lodz, especially } \\
\text { smaller, niche areas; } \\
\text { - the creativity of the team depends on } \\
\text { the budget available; } \\
\text { - existing mental limitations of people }\end{array}$ \\
\hline
\end{tabular}

Source: Author's own study based on research. 
Table 3. External factors (stimuli) from the group of motivators and demotivators influencing the involvement of cultural institutions (CI) employees in building the city's brand in Lodz

\begin{tabular}{|c|c|c|c|}
\hline \multirow{2}{*}{$\begin{array}{l}\text { Grouped subcategories } \\
\text { constituting the values of } \\
\text { the main category, i.e. } \\
\text { external factors }\end{array}$} & \multicolumn{3}{|c|}{$\begin{array}{l}\text { Codes based on the deepened theoretical sampling of analysed interview contents (selective } \\
\text { approach) }\end{array}$} \\
\hline & $\begin{array}{l}\text { Description of } \\
\text { subcategory values }\end{array}$ & $\begin{array}{l}\text { Motivator present based } \\
\text { on studies }\end{array}$ & $\begin{array}{l}\text { Demotivator present based on } \\
\text { research }\end{array}$ \\
\hline $\begin{array}{l}\text { budget/financing of } \\
\text { activities/ employee } \\
\text { salaries }\end{array}$ & $\begin{array}{l}\text { - financial resources } \\
\text { available for the } \\
\text { implementation of } \\
\text { planned activities, } \\
\text { promotion and other } \\
\text { activities aimed at the } \\
\text { development of } \\
\text { institutions and the } \\
\text { city's brand. The } \\
\text { salaries of employees } \\
\text { should also be taken } \\
\text { into account }\end{array}$ & $\begin{array}{l}\text { - cultural institutions can } \\
\text { carry out tasks without a } \\
\text { budget through private } \\
\text { relations and friendship of } \\
\text { CI employees; } \\
\text { - there is support for co- } \\
\text { financing from external } \\
\text { entities: sponsors, guests, } \\
\text { local governments, etc. } \\
\text { - financial assistance } \\
\text { resulting from partnership } \\
\text { cooperation with various } \\
\text { companies and } \\
\text { institutions; } \\
\text { - co-financing of cultural } \\
\text { projects by the entities, to } \\
\text { which the CI is } \\
\text { subordinate (city } \\
\text { authorities), although this } \\
\text { is small money }\end{array}$ & $\begin{array}{l}\text { - often underfunded projects } \\
\text { which cannot be carried out at an } \\
\text { adequate level of quality; there is } \\
\text { not enough for everything; } \\
\text { - lack of money for investment } \\
\text { activities, promotion, etc. } \\
\text { - subsidies received by self- } \\
\text { government entities often suffice } \\
\text { only for "partial maintenance of } \\
\text { buildings and salaries of } \\
\text { employees, which are not high"; } \\
\text { - financial resources are not } \\
\text { "allocated proportionally" to the } \\
\text { tasks performed for the city's } \\
\text { brand }\end{array}$ \\
\hline Documents/strategies/plans & $\begin{array}{l}\text { - tools that make it } \\
\text { possible to learn, } \\
\text { understand and } \\
\text { implement the } \\
\text { recorded strategy; they } \\
\text { determine the } \\
\text { direction of CI } \\
\text { activities }\end{array}$ & $\begin{array}{l}\text { - understanding the } \\
\text { importance of creating } \\
\text { strategic documents and } \\
\text { their sense of existence } \\
\text { for the good of the city's } \\
\text { brand; } \\
\text { - documents are helpful } \\
\text { when competing for equal } \\
\text { competitions aimed at } \\
\text { obtaining financial } \\
\text { resources; they allow for } \\
\text { verification of CI's } \\
\text { activities; } \\
\text { - documents allow the CI } \\
\text { to act coherently to build } \\
\text { the city's brand; } \\
\text { - documents eliminate the } \\
\text { randomness of actions; } \\
\text { - large events } \\
\text { permanently included in } \\
\text { the calendar/city plans }\end{array}$ & $\begin{array}{l}\text { - documents are often considered } \\
\text { to be 'something that simply is'; } \\
\text { 'many entries in documents are } \\
\text { dead, underdeveloped, e.g. ways } \\
\text { of financing were not reasonable'; } \\
\text { - work in culture is "on the verge } \\
\text { of absurdity", "a large creation of } \\
\text { documents as if it were a military } \\
\text { unit"; } \\
\text { - documents and developed } \\
\text { strategies are considered } \\
\text { "uninspiring and unreal"; } \\
\text { - based on documents the CI are } \\
\text { not quite able to define their } \\
\text { position as individuals in the } \\
\text { process of building a city's brand, } \\
\text { they want to know their place in } \\
\text { building a city's brand; } \\
\text { - the schedule of events includes } \\
\text { those of low cultural value; "they } \\
\text { are often not ambitious enough." }\end{array}$ \\
\hline Working conditions & $\begin{array}{l}\text { - affect work } \\
\text { satisfaction; a } \\
\text { comfortable } \\
\text { workplace, equipment } \\
\text { is conducive to greater } \\
\text { involvement; adverse } \\
\text { conditions mean that } \\
\text { people are reluctant to } \\
\text { come to work }\end{array}$ & $\begin{array}{l}\text { - possibility of making } \\
\text { events in unusual places, } \\
\text { "because it attracts } \\
\text { attention", "Lodz has } \\
\text { many such places, e.g. } \\
\text { avant-garde buildings } \\
\text { etc." }\end{array}$ & $\begin{array}{l}\text { - lack of building conditions for } \\
\text { the implementation of specific } \\
\text { tasks resulting from the adopted } \\
\text { CI strategy, but also a limited } \\
\text { possibility to participate in } \\
\text { activities for the city's brand; } \\
\text { - not all CI buildings are in good } \\
\text { condition, no money for } \\
\text { investments }\end{array}$ \\
\hline Work organisation & $\begin{array}{l}\text { - should be adapted to } \\
\text { the skills and } \\
\text { conditions of the CI, } \\
\text { so that it is interesting, } \\
\text { allowing developing } \\
\text { the CI and its } \\
\text { employees. }\end{array}$ & $\begin{array}{l}\text { - organising meetings } \\
\text { with CI employees as a } \\
\text { way to listen to the } \\
\text { employees' opinions;- } \\
\text { dealing with financial } \\
\text { deficiencies using the } \\
\text { skills of their own team of } \\
\text { employees effectively, }\end{array}$ & $\begin{array}{l}\text { - poorly prepared meeting } \\
\text { formulas and inadequately } \\
\text { adjusted meeting times ('late } \\
\text { Friday evening') are not conducive } \\
\text { to the effectiveness of meetings; } \\
\text { - rejection of a large number of } \\
\text { cultural projects and budget cuts } \\
\text { in the projects adopted do not }\end{array}$ \\
\hline
\end{tabular}




\begin{tabular}{|c|c|c|c|}
\hline & & $\begin{array}{l}\text { e.g. they are often forced } \\
\text { to "conduct promotional } \\
\text { activities on their own"; } \\
\text { - organising events in } \\
\text { inspiring places, such as } \\
\text { avant-garde ones, which } \\
\text { attract the attention of the } \\
\text { recipient and influence his } \\
\text { opinion about Lodz, the } \\
\text { place of the event and the } \\
\text { CI; } \\
\text { - allowing CI employees } \\
\text { to create documents } \\
\text { building the city's brand; } \\
\text { - attempts to eliminate } \\
\text { randomness in employing } \\
\text { CI managers }\end{array}$ & $\begin{array}{l}\text { allow the quality of } \\
\text { implementation to be maintained; } \\
\text { - a problem in event management, } \\
\text { i.e. "overlapping of large events } \\
\text { with smaller ones, which results in } \\
\text { no attention being paid to smaller } \\
\text { IK and niche events", which are } \\
\text { great from the perspective of } \\
\text { building the identity of the city; } \\
\text { - lack of "professionalism in CI } \\
\text { management", "randomness in } \\
\text { employing managers" of CI; } \\
\text { - "...dysfunctional promotion } \\
\text { office, does not help much"; } \\
\text { - erroneous delegation of tasks not } \\
\text { following the CI profile; } \\
\text { - last-minute tasks, "lack of time to } \\
\text { complete them"; } \\
\text { - a small number of CI employees } \\
\text { needed to organise events; } \\
\text { - need for CI knowledge and goals } \\
\text { to be achieved in cooperation for } \\
\text { building a city's brand; } \\
\text { - lack of "discussion, disputes, } \\
\text { which are more creative than } \\
\text { documents"; } \\
\text { - lack of assistance from the city } \\
\text { government in finding sponsors } \\
\text { for niche activities; } \\
\text { - lack of partnership exchange } \\
\text { programmes between cities }\end{array}$ \\
\hline Communication tools & $\begin{array}{l}\text { - any use of } \\
\text { communication tools } \\
\text { (marketing-related, } \\
\text { technological } \\
\text { solutions, etc.) to } \\
\text { communicate } \\
\text { information, money, } \\
\text { people, things, ideas, } \\
\text { etc. Bearing in mind } \\
\text { the consistency of } \\
\text { action and building } \\
\text { relationships. }\end{array}$ & $\begin{array}{l}\text { - there are } \\
\text { consultations/meetings } \\
\text { between City Hall and } \\
\text { cultural institutions } \\
\text { - transfer of documents } \\
\text { for building the city's } \\
\text { brand on cultural } \\
\text { resources and general } \\
\text { principles of operation; } \\
\text { - cooperation between CI } \\
\text { based on human, non- } \\
\text { formal friendship } \\
\text { - collaboration on } \\
\text { individual projects } \\
\text { between the CI and the } \\
\text { city government }\end{array}$ & $\begin{array}{l}\text { - it is not known on what basis } \\
\text { cultural institutions are selected as } \\
\text { opinion-making entities at various } \\
\text { events, creating documents, } \\
\text { strategies or cooperation; } \\
\text { - lack of formal programmes } \\
\text { building relations between } \\
\text { institutions involved in the process } \\
\text { of building the city's brand }\end{array}$ \\
\hline
\end{tabular}

Source: Author's own study based on research.

Based on the presented results in Table 2 and Table 3 it can be observed that it is the factors (incentives) from the group of motivators and internal demotivators that have a significant impact on the involvement of employees of cultural institutions in building the city' brand in Lodz. During the analysis there were often statements characterized by the attitude of employees towards actions for the city brand, they often referred to the need for cooperation and building inter-institutional relations. Employees of cultural institutions would also like to feel a sense of meaning from their tasks and would like to see the effects for which they should be appreciated. The government's appreciation of CI's work translates into greater involvement in the next project for the city's brand.

However, appreciation does not have to be of a financial nature, but for example it can be inviting to further projects or asking the CI to express an opinion on actions for 
the city. It should be noted here that CI employees have a fairly high sense of duty and want to perform tasks that are a challenge for them, to feel that they are developing. CIs want to know that city authorities trust them so much that they can make their own decisions about building a city's brand. Cultural people have a high level of creativity, which is often useful in situations where they have to create something for which they have no financial or human resources.

From the group of motivators and external demotivators influencing the involvement of CI employees in building the city' brand in Lodz, documentation including the strategy and action plan is important. It should be designed in such a way that it is an effective tool for the CI to engage in activities for the benefit of the city. It should be understandable and show a clear direction of action. CI managers understand and need documents to act, but if there are too many, they are discouraged. Involvement in activities for the city's brand may also be discouraged by lack or insufficient financial resources for the organisation of events. Working conditions are also important, although, according to many respondents, they have improved in recent years, but some of the tasks commissioned de facto do not match the capacity of their cultural institutions. Tasks for the city are often badly delegated, and not in accordance with the activity profile of a given CI.

\section{Summary}

Every functioning organization should bear in mind that people are its most valuable asset. However, it is often the case that strategies/tasks are more important than the people doing them. This problem was also noticed in interviews with cultural institutions (CI). On the basis of the conducted research, many factors can be observed that may indicate the abandonment of important internal and external motivators for the managers, where these motivators are aimed at involving CI employees - in this case - in the process of building the brand of the city of Lodz regarding cultural resources. This starts from the attitude/relationship of the CI towards the documents provided to them concerning the construction of the city's brand, and ends with the areas of common dialogue, cooperation, or measurement of the effects of the actions (Tables 2 and 3 ).

Based on the analysis of the statements of respondents, the CI manager profile was developed. It, however, requires verification and determination of the impact of this person and CI's co-workers on the process of engaging in city branding. According to the adopted method of analysis, i.e. grounded theory, it would be advisable to present preliminary assumptions which, based on research, may evolve or create new ones. One of the noticed assumptions was the aim of the article itself, which emerged in the previous research of the author for the profile of the manager. ${ }^{29}$ It should be mentioned that the presented descriptions do not constitute the final work on this topic. Interviews with CIs other than the respondents and the city government should also be included. The defined categories presented in this article allow to derive further assumptions for further research, but their description for volumetric reasons has been omitted.

\footnotetext{
${ }^{29}$ The results of these studies, after positive reviews, are awaiting publication.
} 


\section{References}

Bellon M., Szefowa IBM uważa, że zatrudnianie ludzi na podstawie dyplomu, jest blędem, Business Sinder Polska, https://businessinsider.com.pl/rozwoj-osobisty/kariera/kariera-w-branzytechnologicznej-rady-szefowej-ibm/esre9wc (z dnia: 10.02.2019).

Bright L., Public Employees With High Levels of Public Service Motivation: Who Are They, Where Are They, and What do They Want?, „Review of Public Personnel Administration”, Vol. 25. 2, 2005, pp. 138-154.

Bright L., Why Age Matters in the Work Preferences of Public Employees: A Comparison of Three Age-Related Explanations, „Public Personnel Management”, Vol. 39, 1, 2010, pp. 1-14.

Bright L., Where Does Public Service Motivation Count the Most in Government Work Environments? A Preliminary Empirical Investigation and Hypotheses, „Public Personnel Management", Vol.42, 1, 2013, pp. 5-26.

Ciekanowski Z.: Rola menedżera $w$ organizacji, ,Zeszyty Naukowe Uniwersytetu PrzyrodniczoHumanistycznego w Siedlcach. Administracja i Zarządzanie”, z. 34, nr 107, 2015, ss. 185-195. Ciesielska, Lider poszukiwany. Jak stworzyć model kompetencji pożadanego lidera zespołu, „Personel 7 ”, 2007.

Drucker P.F.: Menedżer skuteczny, AE, Kraków 1994; C.S. Nosal: Psychologia myślenia i działania menedżera, AKADE, Kraków 2001; P. Wachowiak: Profesjonalny menedżer, Difin, Warszawa 2001

Foehl P.S., The Cultural Manager:Marginal Notes on a Discussion of Roles and Values, http://www.artsmanagement.net/3b9c996acd3299326518f8e1ff3ad82d,0fm.pdf (27.11.2019). Fohla P.S., Wolframb G., Peperc R., Cultural Managers as 'Masters of Interspaces' in Transformation Processes - a Network Theory Perspective, „Zeitschrift für Kulturmanagement”, 1/2016, S. 17-49 (https://www.netzwerk-kulturberatung.de/content/1-ueber/1-dr-patrick-s-foehl/1publikationen/cultural-managers-as-masters-of-interspaces-in-transformation-processes-anetwork-theory-perspective/b38_zkm2016.1-xx-fohl-et-al-id033.pdf (27.11.2019).

Goldsmith M., Greenberg C., Robertson A., Hu-Chan M.: Globalni liderzy - kolejna generacja, Warszawa 2007, s. 65.

Guryn H.: Czy warto mierzyć zaangażowanie pracowników, „Personel i Zarządzanie” 2009, nr 4. Indisowa L., Kołodziejczyk-Olczak I., Uwarunkowania skutecznego motywowania. Proces komunikacji, Łódź 2000, s. 47.

Informacja o zawodzie - menedżer kultury, 2010, s. 4.

Kania S.: Przewódca jako kreator zmian w organizacji, „Menagement Forum”, vol. 3, no. 2, 2015, ss. $38-43$.

Konecki K.: Studia z metodologii badań jakościowych. Teoria ugruntowana, Warszawa, PWN, 2000, s. 26.

Korczyńska M.: Marka miasta, „Marketing i Rynek”, (12),2002, ss. 2-10.

Kostera M., Kownacki S., Szumski A.: Zachowania organizacyjne: motywacja, przywództwo, kultura organizacyjna, [w:] A. Koźmiński, W. Piotrowski: Zarzqdzanie. Teoria i praktyka, Warszawa 2004, s. 315.

Kotler Ph., Lee N.: Marketing w sektorze publicznym. Mapa drogowa wyższej efektowności, Wyd. Akademickie i Profesjonalne, Wyższa Szkoła Przedsiębiorczości i Zarządzania im. L.

Koźmińskiego, Warszawa 2008.

Krawiec W.: Kreatywność jako determinanta tworzenia wartości i pogtębiania doświadczeń jej odbiorców, Prace naukowe Uniwersytetu Ekonomicznego we Wrocławiu, nr 529, 2018, ss. 129139.

Kuc B., Moczydłowska J.: Zachowania organizacyjne, Warszawa 2009, s. 77.

Lindzey G., Aronson E.: Handbook of Social Psychology, New York, Random House, 1985. 
Machara L., Jain P., Factors affecting staff motivation in public libraries: a case of selected public libraries in Botswana, „Mousaion: South African Journal of Information Studies”, Vol. 34, 1, 2016, pp. $101-122$

Markowski T.: Marketing terytorialny, „Studia KPZK PAN”, t. CXII, 2002.

Matejun M., Dębska S., Non-Economic Incentives to Motivate Employees - Lodz Branch of Norauto Polska Ltd. Example, [in:] D. Lewicka (red.), Organisation Management. Competitiveness, Social Responsibility, Human Capital, AGH University of Science and Technology Press, Krakow 2010, pp. 91-112.

Meyer J.P., Allen N.J., A Tree-Component Conceptualization on Organizational Commitment, „Human Resource Management Review” 1991, No. 1, ss. 61-89.

Niedbalski J.: Komputerowe wspomaganie analizy danych jakościowych. Zastosowanie oprogramowania NVIVO i Atlas.TI w projektach badawczych opartych na metodologii teorii ugruntowanej, Wyd. UŁ, Łódź 2014.

Park S., Motivation of Public Managers as Raters in Performance Appraisal: Developing a Model of Rater Motivation, „Public Personnel Management”, Vol. 43, 4, 2014; pp. 387-414.

Penc J.:, Nowe zarzqdzanie w nowej gospodarce, Wydawca SLG International Training Center, Warszawa 2010.

Penc J.: Motywowanie w zarzqdzaniu, Kraków 1996, s. 203.

Polityka Rozwoju Kultury 2020+ dla Miasta Łodzi.

Raport: Motywacje menadżerów 2016, ARC Rynek i opinie, Warszawa 2016.

Raport GUS: Działalność innowacyjna przedsiębiorstw w Polsce w latach 2013-2015, s. 41-63.

Seweryn R.: Kryzys gospodarczy a ewolucja marki Kraków w opinii hiszpańskich turystów, „Współczesne Zarządzanie” (1), 2013, ss. 51-61.

Simerson K. B., Venn M. L.:, Menedżer jako lider, Oficyna Wolters Kluwer Business, Warszawa. Strategii Zarzadzania Marka Łódź na lata 2010-2016, s. 17-30.

Tomaszuk A.: Sylwetka menedżera w świetle teorii zarzqdzania i badań własnych na przykładzie menedżerów sektora budownictwa województwa podlaskiego, „Economics and Management”, nr 4, 2013, ss. 67-81.7]

Wadden J. D.: Marketing creativity: the influence of personal and proximal work factors on creative activity, ,, Marketing Management Journal”, vol. 21 (2), 2011, s. 73.

Woodman R. W., Sawyer J. E., Griffin R.: Toward a Theory of Organizational Creativity, , Academy of Management Reciew" vol. 18 (2), 1993.

Wierżyński W.: Menedżerowie nowej ery,

http://www.pi.gov.pl/PARP/chapter_86196.asp?soid=4A743DA96D4F422C94CAB3F7CACF303 6, dostęp: 15.11.2018.

Williams M.: Mistrzowskie przywództwo, Oficyna Wolters Kluwer Business, Kraków 2009.

Wright B. E, Kim S., Participation's Influence on Job Satisfaction: The Importance of Job Characteristics, ,Review of Public Personnel Administration”, 24, 1, 2004, pp. 18-40.

Wójtowicz M., Tajemnice motywacji - trzy spojrzenia na problem motywacji pracowników, Good Point, https://goodpoint.blog/tajemnice-motywacji-trzy-spojrzenia-na-problem-motywacjipracownikow/ (z dnia: 24.04. 2017).

\section{Czynniki motywujące i demotywujące menedżerów instytucji kultury w obszarze budowania marki miasta Lodzi - wyniki badań}

\section{Streszczenie}

Celem artykułu jest zidentyfikowanie obszarów/ czynników, które mogą motywować lub też zniechęcać menedżerów instytucji kultury do aktywnego zaangażowania się w proces budowania marki Łodzi o zasoby kultury. 
W artykule opisano profil menedżera instytucji kultury oraz zaprezentowano uporządkowaną lisy czynników (bodźców), które mają pozytywny bądź negatywny wpływ na działania menedżerów instytucji kultury w obszarze kreowania marki miasta.

Podstawę empiryczną artykułu stanowią wywiady przeprowadzone $\mathrm{z}$ menedżerami i pracownikami ds. promocji w miejskich instytucjach kultury w Łodzi. Analiza danych została przeprowadzona zgodnie z zasadami metodologii teorii ugruntowanej. Badania te są prowadzone od grudnia 2017 r. w obrębie Katedry Marketingu oraz Katedry Zarządzania Miastem i Regionem Wydziału Zarządzania Uniwersytetu Łódzkiego w ramach projektu: „Wspótpraca administracji publicznej z instytucjami kultury w kontekście budowania marki miasta”.

Słowa kluczowe: marka miasta, menedżer, teoria ugruntowana, instytucje kultury, motywatory, demotywatory

JEL Codes: M14, M31

Information about authors:

\section{Dr Wioletta Krawiec}

Faculty of Management

University of Łódz

ul. Matejki 22/26

90-237 Łódź

e-mail: wioletta.krawiec@uni.lod.pl

ORCID: 0000-0001-5619-9467 